\title{
E-LEARNING RENDSZEREK A MISKOLCI EGYETEMEN ÉS A KÖNYVTÁRI SZOLGÁLTATÁSOKBAN
}

\author{
Somogyi Aliz \\ Miskolci Egyetem Könyvtár, Levéltár, Múzeum \\ somogyi.aliz@uni-miskolc.hu \\ Szendi Attila \\ Miskolci Egyetem Könyvtár, Levéltár, Múzeum \\ konsendi@uni-miskolc.hu
}

DOI: 10.31915/NWS.2018.14

E-learning systems in library services and at the University of Miskolc The article would like to present [1] how does digital revolution affect our reading and learning habits, including our library usage; [2] what challenges does the educational system have to face because of transformed of readers' communities; [3] how could the libraries re-define their role and tasks in their teaching and learning support system (especially in higher education) and finally [4] how could the Library, Archives and Museum of the University of Miskolc define itself and expand its service palette for higher satisfaction of teachers and students.

\section{Keywords: e-learning}

\section{Bevezetés}

A digitális forradalom és innováció miatti paradigmaváltásnak mindannyian egyszerre vagyunk tanúi és alanyai, ki-ki kisebb vagy nagyobb mértékben. Függetlenül érdeklődési körünktől, beállítódásunktól, korunktól, hivatásunktól vagy épp életmódunktól, a technológiai fejlődés olvasási-tanulási attitűdjeinkre (is) észrevétlenül befolyással van.

Jelen cikk arra próbál rávilágítani, [1] hogy a digitális fejlődés milyen hatást gyakorol az olvasásitanulási, ennél fogva könyvtárhasználati szokásainkra; [2] hogy a megváltozott olvasóközönség milyen kihívások elé állítja az oktatási rendszert (és ehhez kapcsolódóan a könyvtárakat); [3] hogy a fentiek következményeként miért elkerülhetetlen és szükségszerü a (felsőoktatási) könyvtárak oktatás- és tanulástámogatásban betöltött szerepének és feladatainak újradefiniálása; végezetül arra [4], hogy a Miskolci Egyetem Könyvtár, Levéltár, Múzeuma hogyan pozicionálja magát újra és bővíti ki szolgáltatási palettáját az oktatók, hallgatók és a tágabban értelmezett olvasóközönségének nagyobb megelégedése érdekében.

\section{Olvasói-tanulói attitűdváltozás hatása a könyvtárakra}

Pszichológusok, pedagógusok, egyetemi oktatók, szülök és nagyszülök egyöntetü véleménye, hogy a fiatalabb generáció tagjai nem, de legalábbis másképp és mást olvasnak, mint az x vagy annál idősebb korosztályok képviselői. Gyarmathy szerint a digitális korban senki nem olvas már ugyanolyan hatékonyan, mint a múlt században’. Emellett e generáció tartózkodik az élményszerző olvasástól, helyette az információszerzés lett fontosabb, érdekesebb számukra².

Gyarmathy, Éva. „Ki van kulturális lemaradásban?” (2012), http://www.osztalyfonok.hu/cikk.php?id=1018 Greenfield, Patricia M. „Technology and Informal Education: What Is Taught, What Is Learned.” (Science, 2009. Vol. 323, Issue 5910), 69-71. https://doi.org/10.1126/science.11671902009. In: Gombos, Péter, Hevérné Kanyó, Andrea és Kiss, Gábor. „A netgeneráció olvasási attitüdje. 14-18 évesek véleménye könyvekröl, olvasásról, irodalomról - egy felmérés tanulságai”. (Új Pedagógiai Szemle, 2015/1-2) 


\section{NETWORKSHOP 2018}

A fenti tények sokakban régóta azt a jövőképet vizionálják, hogy a könyvtárak elvesztik egykori funkcióikat és alapvető feladataiknak egyre kevésbé van létjogosultságuk a megváltozott olvasói attitűd miatt. E pesszimista utópiát megcáfolta a valóság, hiszen a 21. század sok szempontból a közkönyvtárak reneszánszát hozta. A könyvtárbezárások és a pénzügyi megszorítások ellenére is egyre nyilvánvalóbb, hogy nem volt igazuk azoknak, akik az információs technológia fejlödése következtében a közkönyvtárak halálát jósolták - egyre többen tekintenek a könyvtárakra mint élö, közösségi terekre, sőt, közösségteremtő, a közösségeket alakító, fejlesztő intézményekre. ${ }^{3}$

\section{Megváltozott olvasóközönség: kihívások az oktatási rendszer és ehhez kapcsolódóan a könyvtárak számára}

A technológiai fejlödésnek és a digitális forradalomnak a felnövekvő generációkra gyakorolt hatása a munkáltatókra és munkavállalókra nézve egyaránt új helyzetet teremt. Simai szerint a régi szakismeretek minden korábbinál gyorsabban évülnek el, vagy tartalmuk jelentősen módosul. Új, korábban ismeretlen szakmák tömegei jelennek meg, amelyek kifejlesztésében az iskolarendszernek és a gyakorlatnak egyaránt jelentős a szerepe ${ }^{4}$. A kutatók között nincs egyetértés a munkaerőpiac jövőbeli változásairól. Egyesek munkahelyek nélküli jövőt prognosztizálnak5, mások arra hívják fel a figyelmet, hogy inkább egyfajta átrendeződés történik ${ }^{6}$.

A technológiai fejlődés, valamint az ezek hatására változó munkaerőpiaci elvárások hatással vannak az oktatásra is, ugyanakkor oktatási megoldásaink nem tartanak lépést a technológiai fejlődéssel és a tudományos eredményekkel7. A gyakorlat - sok esetben - ellentétes azzal a gondolatisággal, miszerint az oktatásnak követnie kell a környezeti változásokat, következésképp a könyvtárnak is. Ha változnak az olvasók, a könyvtárnak a könyvtárhasználók változásával együtt kell változnia. Bognárné Lovász Katalin 2011-es cikkében arról ír, hogy a felsőoktatási könyvtárak alapfunkciója az intézményi oktató- és kutatómunka támogatása, szakkönyvtári feladatok ellátása. Az egyetemi könyvtárak munkájának és „hasznosságuknak” megítélése függ attól a képességüktől, hogy hogyan tudják a heterogén egyetemi közösség változó igényeit kielégíteni ${ }^{8}$.

3 Kovácsné Koreny, Ágnes. „Könyvtár és közösség, avagy a közösségvezérelt könyvtár elmélete és gyakorlati megvalósításának lehetőségei”. (Tudományos és Müszaki Tájékoztatás, 65. évf. 2018. 1. sz.), 15.

4 Simai, Mihály. „A tudásalapú társadalom tudománya felé”. (Magyar Tudomány, 2015, 176.2), 132.

5 Ford, Martin. „The Rise of The Robots. Technology and the Threat of a Jobless Future”. (New York: Basic Books, 2015), in Bartha, Zoltán és Sáfrányné Gubik, Andrea. „Oktatási kihívások a technikai forradalom tükrében”. (Észak-magyarországi Stratégiai Füzetek, XV. évf. 2018/1), 20.

6 Bessen, James. „How computer automation affects occupations: Technology, jobs, and skills.” (2016), in Bartha, Z. és Sáfrányné Gubik, A. „Oktatási kihívások...”, 20.

7 in Bartha, Z. és Sáfrányné Gubik, A. „Oktatási kihívások...”, 25.

8 Bognárné Lovász, Katalin. „A felsőoktatási könyvtárak szerepe a tudásmegosztásban”.

(Tudományos és Müszaki Tájékoztatás, 2011, 58. évf. 9. Sz.), 392. 


\section{A felsőoktatási könyvtárak - oktatás- és tanulástámogatásban betöltött - szerepének és feladatainak újradefiniálása}

A felsőoktatási könyvtárra -, amely híd tudás és tanulás, tudomány és oktatás között -, különösen nagy felelösség hárul a jövő oktatási rendszerében. A könyvtáros társadalom egységes állásponton van abban a tekintetben, hogy a könyvtárak alapletéteményesei a tudásgyarapításnak, az oktatásés tanulástámogatásnak, ugyanakkor nincs egyetértés a megváltozott hallgatói és oktatói igények kiszolgálásához való igazodás módjában, mértékében. A könyvtárak szerepeinek változásával kapcsolatosan számos publikáció látott napvilágot. Nagy, Molnár és Kokas ezzel kapcsolatosan kiemelik, hogy nem egy hirtelen bekövetkező, forradalmi átalakulásról van szó, hanem sokkal inkább egy szerves fejlődésről, egy hosszú útról, amelynek során a könyvtár, mint intézmény saját új helyét és szerepeit próbálja megkeresni és megkonstruálni. Ez az útkeresés 15-20 éve intenzíven jelen van a szakmában?.

A magyar szakirodalomban Mader Béla használta először a „hibrid könyvtár” ${ }^{10}$ kifejezést, amelynek értelmében a könyvtáraknak párhuzamosankell ellátniuk a hagyományos könyvtári igényeket, ugyanakkor a digitális világ követelményeinek is meg kell felelniük¹. Bognárné Lovász Katalin szerint a felsőoktatási intézményekben a könyvtárak egyik legfontosabb feladata a tudásmenedzsmenthez kapcsolódik ${ }^{12}$. A változó világhoz alkalmazkodó könyvtári feladatokkal kapcsolatosan több modell került kidolgozásra (ti. szükségletalapú és közösségvezérelt könyvtár modellje) és új típusú megközelítést alkalmaznak a norvégok is, amely szerint a könyvtárban (= digitális tudásközpontban) a könyvtáros, mint guide segít eligazodni13.

Nagy, Molnár és Kokas 2017-es tanulmányukban a Massachusetts Institute of Technology (MIT) könyvtárának előzetes kutatási jelentését elemzik - a jelentés nem egy általános modell, hanem egy szcenáriót vázol fel az egyetemi kutatókönyvtár számára, amely több ajánlást fogalmaz meg. Ezek között a tömeges online kurzusok (Massive Open Online Course, későbbiekben ld. MOOC) is említésre kerülnek, amelyekkel kapcsolatosan az egyetemi könyvtáraknak széles körü feladatai vannak ${ }^{14}$. Nagy Vitéz definiálásában a MOOC-ok olyan, a felsőoktatáshoz köthető, tisztán online e-learning képzések, amelyek az amerikai egyetemek (pl. Stanford, MIT, Harvard) kezdeményezéséből indultak ki, akik egyes képzéseiket teljesen ingyenessé teszik a világon bárki számára15. A felsőoktatásnak ezt a formáját az oktatók azért dicsérik, mert nagy közönséget tudnak elérni, míg a résztvevők számára a rugalmasság, az ingyenesség és az elit egyetemek oktatói által garantált színvonal a fő vonzóerő¹

\footnotetext{
9 Nagy, Gyula, Molnár, Sándor és Kokas, Károly. „A könyvtárak jövőjéről - Reflexiók egy előzetes kutatási jelentés alapján”. (Tudományos és Müszaki Tájékoztatás, 2017. 64. évf. 2. sz.), 67

10 Mader, Béla. „Információs és kommunikációs technológiák kutatási, fejlesztési és innovációs irányai és a könyvtárak". (Tudományos és Müszaki Tájékoztatás, 48. évf. 9-10. sz.), 369.

Nagy, Gy., Molnár, S. és Kokas, K. „A könyvtárak jövőjéről...”, 67.

Bognárné Lovász, K. „A felsőoktatási könyvtárak szerepe...”, 391.

Kovácsné Koreny, Á. , Könyvtár és közösség...”, 16-17.

Nagy, Gy., Molnár, S. és Kokas, K. „A könyvtárak jövőjéröl...”, 71.

Nagy, Vitéz. „E-learning ABC”. (Vezetéstudomány, 2016. XLVII. Évf. 12. szám), 12. https://doi.or 10.14267/ VEZTUD.2016.12.01

16 Drótos, László. „Mit kell tudni a könyvtárosoknak a nyitott online tömegkurzusokról?”.

(Tudományos és Müszaki Tájékoztatás, 2014. 61. évf. 1. sz.), 31
} 


\section{NETWORKSHOP 2018}

Részben a tömeges online kurzusoknak köszönhetö, hogy az MIT esetében a könyvtárosok számára a backoffice-jellegü munkák legalább olyan fontos szerepet töltenek be, mint a személyes, frontofficetípusú könyvtáros-olvasó kapcsolat, azaz a valóságban sokszor nem történik személyes interakció. Ez a jelenség már egyértelműen a könyvtári paradigmaváltás következménye ${ }^{17}$. Drótos László arra hívja fel a figyelmet, hogy az egyetemeken és főiskolákon dolgozó könyvtárosoknakis követniük kell a változásokat, és meg kell határozniuk a felelősségüket, szerepüket a MOOC-ok világában ${ }^{18}$, és arra is szükség van, hogy a könyvtárosok átértékeljék szerepüket és feladataikat, valamint kitágítsák feladatrendszerüket ${ }^{19}$.

\section{A Miskolci Egyetem Könyvtár, Levéltár, Múzeum szolgáltatási palettájának bővítése}

A magyar felsőoktatásban és egyetemi közegben az e-learning leggyakrabban a kevert képzésekben jelenik meg: a hagyományos kurzusokat az innovatív oktatók olyan online tanulási elemekkel egészítik ki, amelyek segítik a hallgatók közötti interakciókat és kommunikációt, magasabb tanulási élményt jelentenek és mélyítik a megszerzett tudást ${ }^{20}$.

A Miskolci Egyetem Könyvtár, Levéltár, Múzeum a hagyományos könyvtári feladatok mellett az e-learning szolgáltatásokkal is foglalkozik a nyílt (mindenki számára ingyenesen elérhető kurzusok), illetve zárt (csak a Miskolci Egyetem oktatói és hallgatói számára biztosított) elektronikus tartalmak, kurzusok szolgáltatásával.

- A Miskolci Egyetem oktatói és hallgatói számára évtizedek óta lehetőség van olyan zárt keretrendszer használatára, amely a hagyományos tantermi oktatás mellett biztosítja az oktatás során használt tananyagok elektronikus elérését.

- 2015-töl létrejött a nyílt platform is: a MeMOOC (Miskolci Egyetem Online Képzési Központja) az amerikai egyetemek mintájára magas színvonalú online kurzusok ingyenes elérését teszi lehetővé mindenki számára. E két, jellegében hasonló, célközönségében eltérő szolgáltatás nyújtását az oktatókkal és a Miskolci Egyetem Informatikai Szolgáltató Központjával karöltve - a Miskolci Egyetem Könyvtár, Levéltár, Múzeum végzi, elindulva ezzel a könyvtári paradigmaváltás útján.

Míg a zárt kurzusok keretrendszere a Moodle, addig a nyílt kurzusoké az Open EDX volt 2018-ig: ebben az évben a MeMOOC is áttért a Moodle keretrendszer alkalmazására részben az egységesség, részben az üzemeltetési-infrastrukturális optimalizálás okán. Megújult portáljainkra 2018 nyarán történik meg a teljes körü átállás.

17 Nagy, Gy., Molnár, S. és Kokas, K. „AA könyvtárak jövőjéröl...”, 66.

18 Drótos, L. „Mit kell tudni a könyvtárosoknak...”, 31.

19 Bognárné Lovász, K. „A felsőoktatási könyvtárak szerepe...”, 392.

20 Nagy, V. ,E-learning ABC”, 12. 
A Miskolci Egyetem központi könyvtárában dolgozó könyvtárosok szerepe az e-learning szolgáltatások nyújtását illetően az alapvető adminisztrátori feladatok (pl. kurzus létrehozása) mellett kiterjed a tananyagok feltöltésére és készítésére, egyedi oktatói kérések teljesítésére (pl. vizsgatesztek beállításainak tesztelésére), statisztikai adatszolgáltatásra és -elemzésre, tréningek és workshopok tartására, valamint az e-learning szolgáltatások népszerüsítésére (intézeti és tanszéki értekezleteken történő bemutatók tartására). Zárt kurzusaink felölelik a Miskolci Egyetem mind a nyolc karának tudományterületét, nyílt kurzusaink inkább műszaki, azon belül is informatikai témákat dolgoznak fel; a kurzusok száma a két rendszerben együttesen több mint háromszázra tehető. A regisztrált felhasználók száma a MeMOOC portálon több mint hétezer, zárt portálunkon pedig hatezer. Mindkét portálon évente átlagosan több mint 500 fő az új belépők száma. 2018-ban a beiratkozások száma alapján a legnépszerübb nyílt kurzusaink az alábbiak voltak: Termelő rendszerek irányítása, Ütemezési modellek és algoritmusok, valamint Számításelmélet.

Mind a nyílt, mind a zárt kurzusaink aszinkron típusúak: a hallgató időben és térben teljesen elkülönül az oktatótól, tehát önállóan és egyedül tanul. Zárt kurzusaink egyértelműen az oktatók és hallgatók támogatását szolgálják a félév során felvett/oktatott tananyagok könnyebb, hatékonyabb, kényelmesebb elsajátítása, elérése érdekében. Nyílt kurzusaink többsége az autodidakta tanulást segíti kreditbeszámítás nélkül, ugyanakkor kurzusaink egy kis részét beszámítjuk az alapképzés során. (Ti. a mérnök-informatikus FOSZ képzés távoktatási formája számos tantárgyat ezen a platformon keresztül oktat. A mérnök-informatikus FOSZ képzés sikeres elvégzését követően az alapképzésen a tárgyak egy része beszámításra kerül.)

Az E-Learning Centrum és a MeMOOC Képzési Központ jövőbeni céljai között szerepel a távoktatás megújítása, valamint a „külvilág” irányába történő nyitás folytatása, fejlesztése.

\section{Irodalomjegyzék}

[1] Bartha, Zoltán és Sáfrányné Gubik, Andrea. „Oktatási kihívások a technikai forradalom tükrében”. (Észak-magyarországi Stratégiai Füzetek, XV. évf. 2018/1), 15-29.

[2] Bessen, James. „How computer automation affects occupations: Technology, jobs, and skills.” (2016) https://doi.org/10.2139/ssrn.2690435

[3] Bognárné Lovász, Katalin. „A felsőoktatási könyvtárak szerepe a tudásmegosztásban”. (Tudományos és Müszaki Tájékoztatás, 2011, 58. évf. 9. sz.), 387-397.

[4] Drótos, László. „Mit kell tudni a könyvtárosoknak a nyitott online tömegkurzusokról?”. (Tudományos és Müszaki Tájékoztatás, 2014. 61. évf. 1. sz.), 31-33.

[5] Ford, Martin. „The Rise of The Robots. Technology and the Threat of a Jobless Future”. (New York: Basic Books, 2015)

[6] Gombos, Péter, Hevérné Kanyó, Andrea és Kiss, Gábor. „A netgeneráció olvasási attitűdje. 14-18 évesek véleménye könyvekröl, olvasásról, irodalomról - egy felmérés tanulságai”. (Új Pedagógiai Szemle, 2015/1-2) 


\section{NETWORKSHOP 2018}

[7] Greenfield, Patricia M. „Technology and Informal Education: What Is Taught, What Is Learned.” (Science, 2009, Vol. 323, Issue 5910), 69-71. https://doi.org/10.1126/science.11671902009.

[8] Gyarmathy, Éva. „Ki van kulturális lemaradásban?, 2012.

http://www.osztalyfonok.hu/cikk.php?id=1018

[9] Kovácsné Koreny, Ágnes. „Könyvtár és közösség, avagy a közösségvezérelt könyvtár elmélete és gyakorlati megvalósításának lehetőségei”. (Tudományos és Műszaki Tájékoztatás, 2018, 65. évf. 2018. 1. sz.), 15-26.

[10] Mader, Béla. „Információs és kommunikációs technológiák kutatási, fejlesztési és innovációs irányai és a könyvtárak". (Tudományos és Müszaki Tájékoztatás, 48. évf. 9-10. sz.), 364-374.

[11] Nagy, Gyula, Molnár, Sándor és Kokas, Károly. „A könyvtárak jövőjéről - Reflexiók egy előzetes kutatási jelentés alapján”. (Tudományos és Müszaki Tájékoztatás, 2017. 64. évf. 2. sz.), 64-82.

[12] Nagy, Vitéz. „E-learning ABC”. (Vezetéstudomány, 2016. XLVII. Évf. 12. szám), 6-15.

[13] Simai, Mihály. „A tudásalapú társadalom tudománya felé”. (Magyar Tudomány, 2015, 176.2), 132-140. 